\title{
The impact of the combination of citrates and acetates on the shelf-life of beef packaged in a modified atmosphere
}

\author{
Aco Kuzelov ${ }^{1}$, Olga Kirovska Cigulevska ${ }^{2}$, \\ ${ }^{1}$ Department for food technology and processing of animal products, Faculty of Agriculture „Goce \\ Delcev“" University Strit Goce Delcev No. 892000 Stip, Republic of Macedonia, \\ ${ }^{2}$ Centar for Public Health-Skopje, III Makedonska brigada, No 18, Skopje, Republic of Macedonia \\ Coresponding author : aco.kuzelov@ugd.edu.mk \\ Original scientific paper
}

\begin{abstract}
Fresh ground beef from the thigh area (Musculus Semimembranosus) was treated with the Bombal Fresh additive (containing a combination of citrates and acetates), with the ratio of $5 \mathrm{~g}$ per $1 \mathrm{~kg}$ of meat. After being treated the meat was vacuumed in a modified atmosphere with a combination of the $\mathrm{O}_{2}$ and $\mathrm{CO}_{2}$ gases with a ratio of 80:20\% and was stored at a temperature of $+2^{\circ} \mathrm{C}$ and $+6^{\circ} \mathrm{C}$ for 8 days. Samples were taken and analyzed on the $1^{\text {st }}, 3^{\text {rd }}$ and $7^{\text {th }}$ day. At the same time control tests were performed on fresh ground beef from the thigh area (Musculus Semimembranosus) that hadn't been treated with Bombal Fresh. The results have demonstrated that the samples that were treated with Bombal Fresh and stored at a temperature of $+2^{\circ} \mathrm{C}$ had a lower bacterial count than the samples stored at a temperature of $+6^{\circ} \mathrm{C}$ and the control samples. The samples treated with Bombal Fresh and stored at a temperature of $+2^{\circ} \mathrm{C}$ received higher organoleptic marks than the samples that were stored at $+6^{\circ} \mathrm{C}$ and the control samples. For all the different sensory properties that were tested (color, discoloration and the intensity of foreign scents) the samples treated with Bombal Fresh and stored at a temperature of $+2^{\circ} \mathrm{C}$ received higher marks than the samples that were stored at $+6^{\circ} \mathrm{C}$ and the control samples.
\end{abstract}

Keywords: citrate, acetate, modified atmosphere, thigh

\section{Introduction}

When producing meat products, meat producers and processors are faced with the task of finding and introducing new technologies for the prevention of the growth of microorganisms, for which key factors are surface contamination and temperature variation or the inability of keeping the cold chain from the start to the end of the handling process of meat and meat products. The challenge of the maintaining of the safety and control of the product is correlated with the way it's packaged, the packaging material, the conditions during producing, storing and distribution, all with the purpose of optimization of the sensory properties and microbiological parameters which are indicators of the safety level of the product (Ercolini et.al., 2006; Paul et.al. 2007; Nuchas et.al., 2008). Fresh ground beef is a product which spoils easily and is sensitive to external factors: temperature, conditions and time of storing, surface contamination and the way it has been 
packaged (Sperber 2010). The deeper layers of tissue in healthy animals are generally sterile (Petaja-Kaminen and Puollane 2007; Petaja et.all 2010; Talon et.al., 2004). When faced with unavoidable temperature variation during the production of meat and meat products, additional steps are needed to insure that the meat and meat products are safe for the consumers. All of these additional steps are combined with meat curing or brining. In the last few years different combinations of salts of organic acids (acetic, lactic, tartaric or citric) have been made that can be applied to the meat during the curing of brining process, or directly (without curing or brining). One such compound is the combination of acetate and citrate. Acetates increase the acidity of the environment where they are applied and so obstruct the growth of meat spoilage bacteria. Citrates penetrate the cells of microorganisms and cause damage to the cell structure (Dragoev 2004). Afterwards the treated meat is packaged under vacuum or in a modified atmosphere $(M A P)$, which is used as an effective way of prolonging the shelf-life and maintaining of the quality of fresh and ground meat (Radetic et.al., 2007; Koustomanis et.al., 2008; Milijasevic et.al., 2008; Ozlemet.al., 2011). MAP is a type of packaging from which air is completely removed and then the vacuum is filled with a gas or a mixture of gases. The goal of this study is to examine the impact of the combination of citrates and acetates on the shelf-life of beef packaged in a modified atmosphere.

\section{Material and Method}

As material we used fresh ground beef from the thigh area (Musculus Semimembranosus). After the butchering and the primary processing, the meat was left to cool for 24 hours at a temperature of $+4^{\circ} \mathrm{C}$, after which the thighs were deboned and categorized. During the deboning process, the bones, tendons and cartilage were removed from the thigh and the pieces of meat were shaped. The beef categorized as class 1 was ground with a Wolf meat grinder with a $5 \mathrm{~mm}$ hole diameter strainer. Afterwards, the ground beef was portioned and placed into vessels measuring $100 \mathrm{~mm}: 180 \mathrm{~mm}: 35 \mathrm{~mm}$ (width: length: height) and vacuumed with a machine that vacuums the meat in a modified atmosphere (MULTIVAC R245), with a combination of inert gasses $\mathrm{O}_{2}: \mathrm{CO}_{2}$ (80:20). The portioned beef was then separated into three groups. A mixture of citrates and acetates (trade name Bombal Fresh, manufactured by Van Hees, Germany) with the ratio of $5 \mathrm{~g}$ per $1 \mathrm{~kg}$ of meat was added to the first and second group. This additive contains E262sodium acetate, cooking salt, E331-sodium citrate and E351-silicon dioxide. The third group wasn't treated with Bombal Fresh and it served as a control group. All the ground beef samples were packaged in a modified atmosphere with a combination of inert gasses $\mathrm{O}_{2}: \mathrm{CO}_{2}(80: 20)$. Finally, they were separated, labeled and stored for 8 days at a temperature of $+2^{\circ} \mathrm{C}$ and $+6^{\circ} \mathrm{C}$. Microbiological tests on the count of aerobic mesophilic bacteria as well as tests on the sensory properties were conducted on the $1^{\text {st }}, 3^{\text {rd }}$ and $7^{\text {th }}$ day. The microbiological tests followed the ISO 4833:2008 method. The tests on the sensory properties were conducted according to the numeric descriptive scale ( ISO 6658:2002) with grades from 1 to 5 , shown on Table 1 . 
Table 1: Quantitative descriptive scale for the grading of the tested sensory properties

\begin{tabular}{|c|l|}
\hline Grade & \multicolumn{1}{|c|}{ Quality level } \\
\hline 5 & Too acceptable \\
\hline 4 & Very acceptable \\
\hline 3 & Acceptable \\
\hline 2 & Borderline acceptable \\
\hline 1 & Unacceptable \\
\hline
\end{tabular}

The following sensory properties were graded: color, discoloration and intensity of foreign scents. The sensory properties of the samples were graded by a panel of 7 experts. The gathered results were mathematically statistically processed with the help of the Microsoft Excel 2003 and its standard add-in program Data Analysis Tool Pak.

\section{Results and discussion}

The results of the microbiological tests are given in Table 2.

Table 2: Total aerobic mesophilic bacteria count $\left(\log { }_{10} \mathrm{cfu} / \mathrm{g}\right)$ in the tested samples

\begin{tabular}{|c|c|c|c|c|}
\hline Days & \multicolumn{2}{|c|}{ Control samples } & \multicolumn{2}{c|}{ Treated samples } \\
& $+2^{\circ} \mathrm{C}$ & $+6^{\circ} \mathrm{C}$ & $+2^{\circ} \mathrm{C}$ & $+6{ }^{\circ} \mathrm{C}$ \\
\hline $1^{\text {st }}$ day & 4,88 & 5,58 & 4,85 & 4,95 \\
\hline $3^{\text {rd }}$ day & 4,52 & 6,85 & 4,22 & 4,55 \\
\hline $7^{\text {th }}$ day & 4,58 & 6,98 & 4,41 & 4,98 \\
\hline
\end{tabular}

We can see from the table that the untreated control samples stored at a temperature of $+2^{\circ} \mathrm{C}$ and $+6^{\circ} \mathrm{C}$ had the highest bacterial count. As early as on the third day of storage, the bacterial count in the untreated samples stored at a temperature of $+2^{\circ} \mathrm{C}$ was determined to be $4,52 \log { }_{10} \mathrm{cfu} / \mathrm{g}$. In the untreated samples stored at a temperature of and $+6^{\circ} \mathrm{C}$ it amounted to $6,85 \log 10 \mathrm{cfu} / \mathrm{g}$. Those samples aren't fit for consumption. On the seventh day of storage, the treated samples that were stored at a temperature of $+2^{\circ} \mathrm{C}$ had a total bacterial count of $4,41 \log { }_{10} \mathrm{cfu} / \mathrm{g}$, and in the treated samples that were stored at a temperature of $+6^{\circ} \mathrm{C}$ it amounted to $4,98, \log _{10} \mathrm{cfu} / \mathrm{g}$. The bacterial count in the untreated samples that were stored at a temperature of $+6^{\circ} \mathrm{C}$ crossed the safe limit of $6,0-6,17$ on the $3^{\text {-rd }}$ and the seventh day of storage. The results of the sensory testing of the samples are given in Table 3 and Table 4.

Table 3: Grading of the sensory properties of the tested samples stored at $+2^{\circ} \mathrm{C}$

\begin{tabular}{|l|c|c|c|c|c|c|}
\hline \multirow{2}{*}{$\begin{array}{l}\text { Sensory } \\
\text { properties }\end{array}$} & \multicolumn{4}{|c|}{ Days } \\
\cline { 2 - 7 } & $1^{\text {st }}$ day & $3^{\text {rd }}$ day & $7^{\text {th }}$ day & $1^{\text {st }}$ day & $3^{\text {rd }}$ day & $7^{\text {th }}$ day \\
\hline \multirow{2}{*}{ Surface color } & 5,00 & 4,90 & 4,82 & 5,00 & 5,0 & 4,92 \\
& $+/-0,0$ & $+/-0,28$ & $+/-0,38$ & $+/-0,0$ & $+/-0,0$ & $+/-0,35$ \\
\hline Cross-section & 5,00 & 4,90 & 4,88 & 5,00 & 5,0 & 4,94 \\
\hline
\end{tabular}




\begin{tabular}{|l|c|c|c|c|c|c|}
\hline color & $+/-0,0$ & $+/-0,30$ & $+/-0,38$ & $+/-0,0$ & $+/-0,0$ & $+/-0,28$ \\
\hline Discoloration & 5,00 & 4,88 & 4,84 & 5,00 & 4,98 & 4,94 \\
& $+/-0,0$ & $+/-0,20$ & $+/-0,25$ & $+/-0,0$ & $+/-0,28$ & $+/-0,22$ \\
\hline Intensity of & 5,00 & 4,28 & 3,23 & 5,00 & 4,38 & 3,52 \\
foreign scents & $+/-0,0$ & $+/-0,52$ & $+/-0,52$ & $+/-0,0$ & $+/-0,58$ & $+/-0,72$ \\
\hline
\end{tabular}

Table 4: Grading of the sensory properties of the tested samples stored at $+6^{\circ} \mathrm{C}$

\begin{tabular}{|l|c|c|c|c|c|c|}
\hline \multirow{2}{*}{$\begin{array}{l}\text { Sensory } \\
\text { properties }\end{array}$} & \multicolumn{7}{|c|}{ Days } \\
& \multicolumn{7}{|c|}{ Control samples } \\
\cline { 2 - 8 } & $1^{\text {st }}$ day & $3^{\text {rd }}$ day & $7^{\text {th }}$ day & $1^{\text {st }}$ day & $3^{\text {rd }}$ day & $7^{\text {th }}$ day \\
\hline \multirow{2}{*}{ Surface color } & 5,00 & 4,88 & 4,80 & 5,00 & 5,0 & 4,90 \\
& $+/-0,0$ & $+/-0,38$ & $+/-0,39$ & $+/-0,0$ & $+/-0,0$ & $+/-0,37$ \\
\hline Cross-section & 5,00 & 4,90 & 4,85 & 5,00 & 5,0 & 4,92 \\
color & $+/-0,0$ & $+/-0,30$ & $+/-0,38$ & $+/-0,0$ & $+/-0,0$ & $+/-0,39$ \\
\hline \multirow{2}{*}{ Discoloration } & 5,00 & 4,87 & 4,82 & 5,00 & 4,98 & 4,90 \\
& $+/-0,0$ & $+/-0,28$ & $+/-0,27$ & $+/-0,0$ & $+/-0,28$ & $+/-0,28$ \\
\hline $\begin{array}{l}\text { Foreign scent } \\
\text { intensity }\end{array}$ & 5,00 & 4,20 & 3,18 & 5,00 & 4,38 & 3,28 \\
$+/-0,0$ & $+/-0,58$ & $+/-0,50$ & $+/-0,0$ & $+/-0,58$ & $+/-0,75$ \\
\hline
\end{tabular}

From the tables we can see that the treated samples that were stored at a temperature of $+2^{\circ} \mathrm{C}$ and $+6^{\circ} \mathrm{C}$ preserved their color the longest, both on the surface and also in the inner layers. The series of untreated samples stored a temperature of $+2^{\circ} \mathrm{C}$ and $+6^{\circ} \mathrm{C}$ performed slightly worse when compared to the treated samples stored at the same temperatures. When the samples were tested for discoloration, the highest marks were again received by the samples that were treated with Bombal Fresh and stored at a temperature of $+2^{\circ} \mathrm{C}$ and $+6^{\circ} \mathrm{C}$, with the untreated samples performing slightly worse. The samples treated with Bombal Fresh and stored at a temperature of $+2^{\circ} \mathrm{C}$ and $+6^{\circ} \mathrm{C}$ received higher marks when tested for the intensity of foreign scents when compared to the untreated samples stored at the same temperatures. By the $7^{\text {th }}$ day, there was a discharge of exudates and an emergence of unacceptable scents in the samples that were stored at a temperature of $+6^{\circ} \mathrm{C}$. The impact of the higher storing temperature was manifested at the $7^{\text {th }}$ day with the discharge of exudates and the emergence of unacceptable scents. The lowest marks for the sensory properties were given to the untreated samples that were stored at $+2^{\circ} \mathrm{C}$ and $+6^{\circ} \mathrm{C}$. The gathered results reflect those of the study by Jayasingh et.al. (2002). The object of their study was ground veal packaged in a modified atmosphere with a high oxygen level. They determined that the color and the bacterial count was the same in the treated and the control samples (as is the case with the samples stored at a temperature of $+2^{\circ} \mathrm{C}$ ). However, the thiobarbituric acid value, which serves as an indicator of the oxidation level as well as the sensory acceptability of meat when packaged in a high oxygen level atmosphere, was much worse after the $6^{\text {th }}$ and $10^{\text {th }}$ day when compared to the control samples. Ercolini et.al., (2006) determined that there was a slow growth of lactic acid bacteria in the samples of fresh beef which has been packaged in a modified 
atmosphere with a $60 \% \mathrm{O}_{2}$ to $40 \% \mathrm{CO}_{2}$ ratio. They came to the realization that ground beef samples in retail can keep the acceptable color without the emergence of undesirable scents for up to 5 days if they are stored at a temperature of $+4^{\circ} \mathrm{C}$. In the samples that were stored at a temperature of $+25^{\circ} \mathrm{C}$ undesirable changes and microbial growth over the safe limits appeared after 12 hour storage. Ozlem et.al., (2011) concluded that packaging ground beef in a modified atmosphere with a $70 \% \mathrm{O}_{2}$ to $30 \% \mathrm{CO}_{2}$ ratio was conductive to the growth of the lactic acid bacteria.

\title{
Conclusion
}

With the addition of a combination of citrates and acetates, there was a perceivable improvement of the microbiological environment and the organoleptic grades of the treated samples when compared to the control samples. When looking at the results of the microbiological tests, the treated samples stored at $+2^{\circ} \mathrm{C}$ and $+6^{\circ} \mathrm{C}$ demonstrated a reduction in the quantity of microorganisms when compared to the untreated samples stored at the same temperatures. The impact of higher temperature at the $7^{\text {th }}$ day of storing was manifested by the discharge of exudates and the emergence of scents that are unacceptable for fresh meat. The gathered results from the research demonstrate that there is a clear impact of the compound composed of acetates and citrates accompanied by vacuuming with inert gasses on the prolongation of the shelf-life of ground beef. Further research should focus on determining on how citrates and acetates combine with other salts and the duration of storing.

\section{Uticaj kombinacije citrate I acetate na odrzlivost govedjeg mesa pakovanog u modificiranu atmosferu}

\author{
A.Kuzelov, Olga Kirovska Cigulevska
}

\section{Rezime}

Sveže govedje meso od buta ( Musculus Semimembranosus) tretirano sa preparatom Bombal fresch (koji sadrži kombinaciju citrate i acetate) u količini od 5gr. na kilogram mesa. Nakon tretiranja meleno meso je vakumirano u modificiranu atmosferu sa kombinacijom gasova $\mathrm{O}_{2}$ i $\mathrm{CO}_{2} 80 \%$ : $20 \%$ i cuvano na temperature od 2 i $6{ }^{\circ} \mathrm{C} 8$ dana. Uzorci su analizirani 1-og, 3-ceg, I 7 -og dana Izradjeni su i kontrolne probe svežeg govedjeg melenog mesa od buta (Musculus Semimembranosus) bez aplikacije bombal fresa.

Rezutati su pokazali da uzorci tretirani sa bombal fres čuvani na temperature od $2^{\circ} \mathrm{C}$ su imali manji ukpni broj bakterija u poredjenu sa uzorcima čuvanih na temperature od $6{ }^{\circ} \mathrm{C}$ i kontrolnih uzoraka. Uzorci tretirani sa bombal fresom čuvani na temperature od $2{ }^{\circ} \mathrm{C}$ dobile su bolje senzorne ocene od uzoraka čuvanih na temperature od $6^{\circ} \mathrm{C}$.

Klucne reci : citrati, acetati, modificirana atmosfera, but 


\section{References}

DRAGOEV S, 2004. Development of technology in the industry for temperature had on good sensory characteristics of meat cuts that meat and fish. Academic Edition UFT Plovdiv, 259-263.

ERCOLINI D, RUSSO F, TORRIERI E, MASI P, VILLANI F, 2006. Changes in the spoilage-related microbiota of beef during refrigerated storage under different packaging conditions.Applied and Environmental Microbiology, 72, 4663-4671. ISO 4833:2008. Microbiology of food and animal feeding - horizontal method for determining the number of microorganisms technique of counting colonies at 30 ${ }^{\circ} \mathrm{C}$.

ISO 6658 : 2002. Quantitative descriptive sensory analisis test, Methodology, General Guide .

JAYSINGH P, COMFORT DP, BRENNAND CP, CARPENTER SE, WHITTIER DR, 2002. Sensory Evalution of Ground Beef Stored in High - oxygen Modified Atmosphere Packaging Journal of Food Science Volume 67 Issue 9 pages 3493 - 3496 November 2002.

KOUTSOUMANIS KP, STAMATIOU AP, DROSINOS EH, NYCHAS GJE, 2008. Control of spoilage microorganisms in minced pork by a self-developed modofi ed atmosphere induced by the respiratory activity of meat microfl ora.Food Microbiology, 25

MILIJAŠEVIĆ M, VELEBIT B, TURUBATOVIĆ L, JOVANOVIĆ J, BABIĆ J, 2008. Uticaj različitih smeša gasova na održivost svežeg junećeg mesa.

Tehnologija mesa, 49,5-6.161-164.

NYCHAS GJE, SKANDAMIS PN, TASSOU CC, KOUTSOUMANIS KP, 2008.

Meat spoilage during distribution. MeatScience, 78, 77-89.

OZLEM K. E. IRKIN R, DEGIRMENCIOUGLU N, DEGIRMENCIOGLU A, 2011. The effects of modifi ed atmosphere gas composition on microbiological criteria, color and oxidationvalues of minced beef meat. Meat Science, 88, 221226.

PETAJA-KANNINEN E, PUOLANNE SPERBER WH, 2010. Introduction to the microbial spoilage of foods and beverages. In: Sperber WH, Doyle MP, editors.Compendium of themicrobial spoilage of foods and beverages.Springer, N.Y., $1-40$.

PETAJA-KANNINEN E, PUOLANNE E, 2007. Principles of Meat Fermentation. In: F. Toldra (Ed.) Handbook of Fermented Meat and Poultry. Blackwel 1Publishing, 31-36.

PAUL, S.K.G. SAMANTA, G. HALDER, P.BISWAS( 2007); Effect of combination of organic acid salts as antibiotic replacer on the performance and $\mathrm{g}$ ut health of broiler cikens . Livestock Research for rural development 19,1 -8.

RADETIĆ P, MILIJAŠEVIĆ M, JOVANOVIĆ J, VELEBIT B, 2007. Pakovanje svežeg mesa u modifi kovanoj atmosferi - trend koji traje. Tehnologija mesa 48, 12, 99-108. 
SPERBER W. H., 2010. Introduction to the microbial spoilage of foods and beverages In: Sperber WH, Doyle MP, editors. Compendium of themicrobial spoilage of foods and beverages. Springer, N.Y., 1-40.

TALON R., LEROY S., FADDA S., 2004. Dry fermented sausages. In : YH Hui, L Meunier-Goddik, ÅS Hansen, J Josephsen, W-K Nip, PS Stanfi eld, F Toldrá, eds. Handbook of Food and Beverage Fermentation Technology. New York: Marcel Dekker, Inc., 397-416. 

